\title{
PESTICIDES: PHYSIOLOGICAL EFFECTS ON SOIL MICROFLORA
}

\author{
Adegboyega, D. A ${ }^{1}$, Akala, A. $O^{2}$., Akanni, F. ${ }^{2}$ Ademuwagun, A.A ${ }^{3}$, Olatunji, A.O ${ }^{4}$ and Eniola. $O^{5}$ \\ ${ }^{1}$ Pathology Section, Department of Forest Conservation and Protection \\ ${ }^{2}$ Biotechnology Section, Bioscience Department, Forestry Research Institute of Nigeria, Ibadan \\ 3 Federal College of Forestry Mechanization, Afaka, Kaduna. \\ ${ }^{4}$ Soils and Tree Nutrition Department \\ ${ }^{5}$ Agricultural Extension and Management Department, Federal College of Forestry, Ibadan
}

https://doi.org/10.35410/IJAEB.2020.5550

\begin{abstract}
The extensive and inappropriate use of pesticides for increased crop yields due to their local formulation and easy availability can be a significant source of surface water, groundwater, air, and soil contamination which adversely affect soil microbial community. This work review on the possible effects of pesticides on the soil microflora.
\end{abstract}

Keywords: Pesticides, Soil, Contamination, Microflora.

\section{INTRODUCTION}

The problem of environmental contamination by pesticides goes beyond the locality where it is used. The agricultural pesticides that are exhaustively applied to the land surface travel long distances and can move downward until reaching the water table at detectable concentrations, reaching aquatic environments at significantly longer distances

Therefore, the fate of pesticides is often uncertain; they can contaminate other areas that are distant from where they were originally used. Thus, decontaminating pesticide-polluted areas is a very complex task (Gavrilescu, 2005).

About $30 \%$ of agricultural produce is lost due to pests. Hence, the use of pesticides has become indispensable in agriculture. The abusive use of pesticides for pest control has been widely used in agriculture. However, the indiscriminate use of pesticides has inflicted serious harm and problems to humans as well as to the biodiversity (Gavrilescu, 2005; Hussain et al., 2009).

Decontamination of pesticide-infested environments is a difficult matter and can be very costly. In fact, the damages from pesticides in the environment are practically irreparable. Any measure used to decrease the effects of pesticides in the environment will always be a palliative solution and never definitive for the problems caused. Regrettably, there is always irreparable damage to the organisms and the environment, as for instance, the extinction of bird species and microorganisms in the world. The biological methods are advantageous to decontaminate areas that have been polluted by pesticides. These methods consider the thousands of microorganisms in the environment that in order to survive seek for alternatives to eliminate the pesticides that 
Vol. 5, No. 05; 2020

ISSN: $2456-8643$

were sprayed. Many native microorganisms develop complex and effective metabolic pathways that permit the biodegradation of toxic substances that are released into the environment. Although the metabolic process is lengthy, it is a more viable alternative for removing the sources of xenobiotic compounds and pollution (Diaz, 2004; Schoefs et al., 2004; Finley et al., 2010).

On account of the grave risks synthetic pesticides pose to the organisms, there is an incessant search for pesticide safety and for the development of sustainable agriculture. The biological pesticides are based on natural compounds that effectively control the infestation of pests in agriculture. The advantage is that, contrary to synthetic pesticides, they are efficient and do not cause collateral damage (Fravel, 2005; Gerhardson, 2002; Raaijmakers et al., 2002).

\section{Degradation of Pesticides in Soil}

Pesticides in the soil environment are subject to a variety of degradative processes. The overall degradation of a pesticide from soil results from a combination of loss mechanisms. The degree to which each mechanism will contribute to the overall loss of the pesticide is in turn dependent on the physico-chemical properties of the pesticides, characteristics of the soils, environmental conditions and management practices. The studies in respect of the salient factors that determine the degradation of pesticides are presented.

\section{Concentration}

Concentration of pesticide application is an important parameter in determining the rate of biodegradation. The degradation kinetics of many pesticides approaches first order; the rate of degradation decreases roughly in proportion with the residual pesticide concentration (Topp et al., 1997). Gupta and Gajbhiye (2002) reported that the half-life of flufenacet in three Indian soils, viz., inseptisol, vertisol and ultisol, varied from 10.1 to 31.0 days at low rate $\left(1.0 \mu \mathrm{g} \mathrm{g}^{-1}\right.$ soil) compared to 13.0 to 29.2 days at high rate $\left(10.0 \mu \mathrm{g} \mathrm{g}^{-1}\right.$ soil $)$ of application. Prakash and Suseela Devi (2000) reported the reduced degradation rate of butachlor at higher initial concentrations, which could be attributed to limitation in the number of reaction sites in soil and toxic effect on microorganisms or enzyme inhibition. Yu et al. (2003) reported that the half-lives of butachlor in non-rhizosphere, wheat rhizosphere and inoculated rhizosphere soils ranged from (6.3 to 18.0$)$ days at $1.0 \mathrm{mg} \mathrm{kg}^{-1}$, (2.9 to 19.9 ) days at $10.0 \mathrm{mg} \mathrm{kg}^{-1}$ and (10.8 to 23.2 ) days at $100.0 \mathrm{mg} \mathrm{kg}^{-1}$ indicating the degradation of butachlor to be dependent on application rate and soil type.

\section{Solubility}

Pesticides with low water solubility tend to be more resistant to microbial degradation than compounds of higher water solubility. Microorganisms can use only the dissolved fraction of the compound in soil solution. Therefore, the rate of dissolution of pesticides would govern the rate of their biodegradation (Cork and Krueger, 1991).

\section{Soil Types}

Soil properties like organic matter, clay content, $\mathrm{pH}$ etc. affect the degradation of pesticides in soil (Gupta and Gajbhiye, 2002). The role of the soil in pesticide biodegradation is critical because it provides the environment for degradative microorganisms. Soil particles 
Vol. 5, No. 05; 2020

ISSN: $2456-8643$

can sorb pesticides, regulating their bioavailability and influencing their persistence. Both content and type of clay and organic matter are important soil parameters, which influence the activity of pesticide degrading microorganisms. Therefore, it is important to study the effect of soil types in pesticide degradation. Gold et al. (1996) reported that soil $\mathrm{pH}$ and clay content greatly affected the persistence of bifenthrin, chlorpyriphos, cypermethrine, fenvelerate, permethrin and isofenphos under field conditions. The half-lives of rim sulfuron under field conditions varied within a wider range of 5.6 days in a sandy clay loam soil in the United States (Schneiders et al., 1993) and of 120 days in a light sandy soil in Denmark (Reinke et al., 1991). Jones and Ananyeva (2001) reported that the degradation of metalaxyl and propachlor occurred at different rates in different soils. The half-lives in pasture, arable and pine forest soils were 10,19 and 36 days for metalaxyl and 2.6, 6.1 and 8.2 days for propachlor. Gupta and Gajbhiye (2002) stated that the degradation of flufenacet was greatly influenced by soil types and the half-life values varied from 10.1 to 22.3 days in an inseptisol, 10.5 to 24.1 days in a ultisol and 29.2 to 31.0 days in a vertisol. Hafez and Thiemann (2003) mentioned that the degradations of imidacloprid and diazinon were faster in the silty loam soil followed by sandy loam and sandy soil. Degradation of pencycuron was soil dependent (Pal et al., 2005b). Pencycuron degraded faster in coastal saline soil than alluvial soil and in soil amended with decomposed cow manure whereas microbial mediated degradation of pencycuron was more in alluvial soil than in coastal saline soil.

\section{Moisture}

Water acts as solvent for pesticides movement and diffusion and is essential for microbial functioning. Pesticide degradation is slow in dry soils. The rate of pesticide transformation generally increases with water content. In very wet soils such as rice paddies, the rate of diffusion of atmospheric oxygen into the soil is limited and anaerobic pesticide transformation can prevail over aerobic degradation. Poor oxygen transfer at high moisture content can, however, accelerate or retard the degradation of pesticides. Phorate was more persistent in flooded soil than in nonflooded soil (Walter-Echols and Liechtenstein, 1978). The herbicides atrazine and trifluraline disappeared more rapidly under anaerobic conditions than under aerobic conditions. The insecticide $\gamma$-BHC persists for several years in aerobic soils, but it is biodegraded partly in submerged soils and a high content of organic matter hastens the biodegradation (Ponnamperuma, 1972). DDT is fairly stable in aerobic soils, but is degraded rapidly to DDD in submerged soils (Topp et al., 1997). The alteration in the oxidation state is important in microbes-pesticides interaction because the oxidized or reduced forms of pesticides often determine their toxicity in the environment through adsorption, solubility etc. (Hicks et al., 1990) and also the microbial activity under submerged condition. Thus, the transformation of pesticides in the submerged soils is different from that of the soils in field moist state. In contrast, Baskaran et al. (1999) reported that soil moisture content had no effect on the degradation of imidacloprid and bifenthrin. Racke et al. (1994) also found similar type of behaviour while studying the degradation of chlorpyriphos. Schneiders et al. (1993) reported that the half-lives of rimsulfuron were 24.5 and 22.5 days under anaerobic and aerobic conditions respectively in a sandy loam soil. Pencycuron degraded rapidly in aerobic soil compared the submerged soil (Pal et al., 2005b). 
Vol. 5, No. 05; 2020

ISSN: $2456-8643$

\section{Structure}

The structure of a pesticide molecule determines its physical and chemical properties and inherent biodegradability. The introduction of substituents on a benzene ring influences its degradation. Minor alterations in structure frequently cause a drastic change in the susceptibility of a compound to biotransformations. Introduction of polar groups such as $\mathrm{OH}, \mathrm{COOH}$ and $\mathrm{NH}_{2}$ may provide the microbial system, a site of attack. Halogen or alkyl substituents tend to make the molecule more resistant to biodegradation (Cork and Krueger, 1991). Chlorinated hydrocarbons such as DDT, pentalene and dieldrin are insoluble in water, sorb tightly to soil and are thus relatively unavailable for biodegradation. The insecticide carbofuran and the herbicide 2,4-D, which are of different molecular structure, can be degraded in a matter of few days in field soils. Minor differences in the position or nature of substituents in pesticides of the same class can influence the rate of degradation (Topp et al., 1997)

\section{Temperature}

The effect of temperature on pesticide degradation depends on the molecular structure of the pesticide. Temperature affects adsorption by altering the solubility and hydrolysis of pesticides in soil (Burns, 1975, Racke et al., 1997). As adsorption processes are exothermic and desorption processes are endothermic, it is expected that adsorption will reduce with increase in temperature with a corresponding increase in pesticide solubility. Vischetti et al. (1995) found that the half-lives of rimsulfuron ranged from 14.8 days at $10^{\circ} \mathrm{C}$ to 3.5 days at $25^{\circ} \mathrm{C}$ in a clay loam soil incubated at $75 \%$ humidity. Microbial activity is stimulated by increase in temperature and some ecological groups tend to dominate within certain temperature ranges. Perucci et al. (1999) studied the effect of rimsulfuron on the growth and activity of microbial biomass under laboratory conditions at varying conditions of temperature in a silty clay loam soil. The onset and magnitude of the effects were temperature dependent and generally slight and transitory. Rimsulfuron hydrolyses rapidly in soil under conditions of high temperature (Vischetti et al., 2000). The maximum growth and activity of microorganisms in soils occur at $25-35^{\circ} \mathrm{C}$ (Alexander, 1977) and the pesticide degradation is optimal at mesophillic temperature range of around $25-40^{\circ} \mathrm{C}$ (Topp et al., 1997). Jitender et al. (1993) conducted laboratory experiments with thiobencarb and butachlor incubated at 25 and $35^{\circ} \mathrm{C}$ for 90 days and observed a direct relationship between temperature and pesticide concentration-lower temperature and higher concentration resulted in greater persistence. Getzin (1981) observed that the half-lives of chlorpyriphos ranged from $>20$ to 1 day over the temperature range of 5 to $45^{\circ} \mathrm{C}$, respectively. Zhu et al. (2004) reported faster degradation of fipronil at $35^{\circ} \mathrm{C}$ than at $25^{\circ} \mathrm{C}$ in non sterile clay loam soil.

\section{pH}

Soil $\mathrm{pH}$ may affect pesticide adsorption, abiotic and biotic degradation processes (Burns, 1975). It influences the sorptive behavior of pesticide molecules on clay and organic surfaces and thus, the chemical speciation, mobility and bioavailability (Hicks et al., 1990). For instance, the sorption of prometryn to clay montmorillonite is more at $\mathrm{pH} 3$ than at $\mathrm{pH} 7$ 
(Topp et al., 1997). The effect of soil $\mathrm{pH}$ on degradation of a given pesticide depends greatly on whether a compound is susceptible to alkaline or acid catalyzed hydrolysis (Rackeet al., 1997). Rimsulfuron hydrolyses rapidly in soil under conditions of high temperature (Vischetti et al., 2000).

\section{Salinity}

Limited information is available on the degradation of pesticides in saline soils although salinity is a severe problem in many arid, semiarid and coastal regions. Parathion was degraded faster in nonsaline soil than in saline soils and its stability increased with increasing electrical conductivity (Reddy and Sethunathan, 1985). However, reports on the stability of pesticides in estuarine and seawater of varying degrees of salinity are available. A high salt content in seawater may be innocuous (Walker, 1976) or inhibitory to degradation (Weber, 1976; Kodama and Kuwatsuka, 1980). Degradation of pencycuron was less in the coastal saline soil compared to the alluvial soil (Pal et al., 2005b).

Physiological Effects of Pesticides on soil microbes

The effect of pesticides varied greatly with the type, rate, and time after application of pesticides. Efforts must be made to determine the proper type and dosage of pesticide for agricultural crops in order to prevent their adverse effect on the environment in general and on useful soil organisms in particular. When pesticides are applied, the possibilities exist that these chemicals may exert certain effects on nontarget organisms, including soil microorganisms (Zhao et al., 2013).

The microbes play an important role in the soil ecosystem (Khan et al., 2010), and their functions (Khan et al., 2007) are very crucial in nutrient cycling and decomposition (Lorenzo et $a l ., 2001)$. The study of pesticide effects on non-target populations is an accepted strategy to evaluate its associated potential environmental risks. Among non-target populations, soil microorganisms are extremely important, since they play an essential role in nutrient turnover (Aneja, 2004), maintaining generative capacity in agro-ecosystems (Bohlen, 2002). The processes of ecological succession are, among other factors, mediated by microorganisms and depend on a fine balance of their population dynamics (Kennedy, 1999). Under these circumstances, the impact inflicted on soil microbial populations caused by a specific pesticide is a potential indicator of the toxicity level of this product, and may represent a component of a broad study aiming to evaluate its potential impact on the environment (Kent, 2002).

\section{REFERENCES}

Adam, G. and H. Duncan, 2001. Development of a sensitive and rapid method for the measurement of total microbial activity using fluorescein diacetate (FDA) in a range of soils. Soil Biol. $\quad$ Biochem., $\quad 33:$ 943-951.

Adhya, T.K., P.A. Wahid and N. Sethunathan, 1987. Persistence and biodegradation of selected organiphosphorous insecticides in flooded versus non-flooded soils. Biol. Fertil. Soils,

4: 36-40. 
Akhtar, M., M. Saeed, S.K. Tanveer and A. Iqbal, 2000. Response of fourth ratooning of sugarcane to different patterns of plantation and seeding densities. Pak. J. Biol. Sci., 3: 1574-1576.

Alef, K., 1995. Estimation of Soil Respiration. In: Methods in Applied Soil Microbiology and Biochemistry, Alef, K. and P. Nannipieri (Eds.). Academic Press, London, pp: 215-216. Alexander, M., 1977. Introduction to Soil Microbiology. 2nd Edn., Wiley Eastern Ltd., New Delhi, India.

Alexander, M., 1994. Biodegradation and Bioremediation. Academic Press, New York Pages:692.

Ananyeva, N.D., T.S. Demkina and U.C. Stin, 1997. The stability of microbial communities in pesticide-treated soils. Pochvovedenic, 1: 69-74. Anderson, J.P.E. and K.H. Domsch, 1978. A physiological method for the quantitative measurement of microbial biomass in soils. Soil Biol. Biochem., 10: 215-221. Anderson, J.P.E. and K.H. Domsch, 1985. Maintenance carbon requirements of actively metabolising microbial populations under in situ situations. Soil Biol. Biochem., 17: 197203.

Anderson, J.P.E., 1981. Methods to evaluate pesticide damage to the biomass of the soil microflora. Soil Biol.

Biochem., 13:

$149-153$. Anderson, J.R., 1978. Some Methods for Assessing Pesticide Effects on Nontarget Soil Microorganisms and Their Activities. In: Pesticide Microbiology, Hill, I.R. and S.J.L. Wright (Eds.). Academic press, London, pp: 247-312. Anderson, T.H. and K.H. Domsch, 1985. Determination of eco-physiological maintenance requirements of soil microorganisms in a dormant state. Biol. Fert. Soils, 1: 81-89. Anderson, T.H. and K.H. Domsch, 1990. Application of eco-physiological quotients $\left(\mathrm{qCO}_{2}\right.$ and $\left.\mathrm{qD}\right)$ on microbial biomasses from soils of different cropping histories. Soil Biol. Biochem., 22:

251-255 Araujo, A.S.F., R.T.R. Monteiro and R.B. Abarkeli, 2003. Effect of glyphosate on the microbial activity of two Brazilian soils. Chemosphere, 52: 799-804. Atlas, R.M., D. Pramer and R. Bartha, 1978. Assessment of pesticide effects on non-target soil microorganisms. Soil Biol. Biochem., 10: 231-239. Banerjee, A., S. Padhi and T.K. Adhya, 1999. Persistence and biodegradation of vinclozolin in tropical rice soils. Pest. Sci., 55: 1177-1181. Baskaran, S., R.S. Kookana and R. Naidu, 1999. Degradation of bifenthrin chlorpyriphos and imidacloprid in soil and bedding materials at termiticidal application rates. Pest. Sci., 55:

1222-1228.

Beigel, C., M.P. Charnay and E. Barriuso, 1999. Degradation of formulated and unformulated triticonazole fungicide in soil effect of application rate. Soil Biol. Biochem., 31:

$525-534$

Brookes, P.C., A.A. Newcombe and D.S. Jenkinson, 1987. Adenylate energy charge measurement in soil. Soil Biol. Biochem., 19: 211-217. Burns, R.G. and J.A. Edwards, 1980. Pesticide breakdown by soil enzymes. Pest. Sci., 11: 506-512.

Burns, R.G., 1975. Factors Affecting Pesticide Loss from Soil. In: Soil Biochemistry, Paul, E.A. and A.D. McLaren (Eds.). Marcel Dekker, Inc., New York, USA., pp: 103-141. 
Butcher, J.W., E. Kirkuel and M. Zabik, 1969. Conversion of ddt to dde by Folsomia candida. Rev. Ecol. $\quad$ Biol. Soil, 6: 291-298. Cheng, W., Q. Zhang, D.C. Coleman, C.R. Caroll and C.A. Hoffmann, 1996. Is available carbon limiting microbial respiration in the rhizosphere Soil Biol.Biochem.,28:1283-1288. Cork, D.J. and J.P. Krueger, 1991. Microbial transformation of herbicides and pesticides.Adv.AppliedMicrobiol.,36:1-66.

Davis, M.W. and R.T. Lamar, 1992. Evaluation of methods to extract ergosterol for quantification of soil fungal biomass. Soil Biol. Biochem., 24: 189-198.

Diaz, E. (2004). Bacterial Degradation of Aromatic Pollutants: A Paradigm of MetabolicVersatility, International Microbiology, Vol. 7, No. 3, (September 2004), pp. 173-180, ISSN

1139-6709.

Dick, R.P., 1994. Soil Enzyme Activities as Indicators of Soil Quality. In: Soil Enzymes, Doran, J.W., D.C. Coleman, D.F. Bezdicek and B.A. Stewart (Eds.). Soil Science Society of America, Madison, WI., 107-124. Dick, R.P., D.P. Breakwell and R.F. Turco, 1996. Soil Enzyme Activities and Biodiversity Measurements as Integrative Microbiological Indicators. In: Handbook of Methods for Assessment Soil Quality, Doran, J.W. and A.J. Jones (Eds.). Soil Science Society of America, Madison, WI., pp: 247-272. Djajakirana, G., R.G. Joergensen and B. Meyer, 1996. Ergosterol and microbial biomass relationship in soil. Biol. Fertil. Soils, 22: 299-304. Domsch, K.H., 1984. Effects of pesticides and heavy metals on biological processes in soil. Plant Soil, 76: 367-378. Doran, J.W. and T.B. Parkin, 1994. Defining and Assessing Soil Quality. In: Defining Soil Quality for a Sustainable Environment, Doran, J.W., D.C. Coleman, D.F. Bezdicek and B.A. Stewart (Eds.). Soil Science Society of America, Madison, WI., USA., pp: 3-21. Duah-Yentumi, S. and D.B. Johnson, 1986. Changes in soil microflora in response to repeated applications of some pesticides. Soil Biol. Biochem., 18: 629-635. Elliot, L.F., J.M. Lynch and R.I. Papendick, 1996. The Microbial Component of Soil Quality. In: Soil Biochemistry, Stotzky, G. and J.M. Bollag (Eds.). Marcel Dekker, Inc., New York, USA., $\quad$ pp: 1-21. Entry, J.A. and W.H. Emmingham, 1996. Influence of vegetation on microbial degradation of atrazine and 2,4-dichlorophenoxyacetic acid in riparian soils. Can. J. Soil Sci., 76: 101106.

Entry, J.A., P.K. Donelly and W.H. Emmingham, 1994. Microbial mineralization of atrazine and 2,4-dichlorophenoxyacetic acid in riparian pasture and forest soils. Biol. Fertil. Soils, 18:

89-94.

Farmer, V.C. and R.I. Morrison, 1964. Lignin in sphagnum and phragmites and in peats derived from these plants. Geochim. Cosmochim. Acta, 28: 1537-1546. Finley, S.D.; Broadbelt, L.J. \& Hatzimanikatis, V. (2010). In Silico Feasibility of Novel Biodegradation Pathways for 1,2,4-Trichlorobenzene, BMC Systems Biology, Vol.4,No.7, (February 2010), pp.4-14, ISSN 1752-0509.

Fravel, D.R. (2005). Commercialization and Implementation of Biocontrol, Annual Review of Phytopathology, Vol.43, (July 2005), pp. 337-359, ISSN 0066-4286. 
Vol. 5, No. 05; 2020

ISSN: $2456-8643$

Gavrilescu, M. (2005). Fate of Pesticides in the Environment and its Bioremediation, Engineer in Life Science, Vol.5, No. 6, (December 2005), pp. 497-526, ISSN 1618-2863.

Gerbar, H.R., J.P.E. Anderson, B. Bugel-Mongensen, D. Castle and K.H. Domsch et al., 1989. Revision of recommended laboratory tests for assessing side effects of pesticides on soil microflora. Proceedings of the 4th International Workshop, Leverkusen.

Gerhardson, B. (2002). Biological Substitutes for Pesticides, Trends in Biotechnology, Vol. 20,No. 8, (August 2002), pp. $338 \quad 343$, ISSN 0167-9430. Getzin, L.W., 1981. Dissipation of chlorpyriphos from dry soil surfaces. J. Econ. Entomol74:

707-713.

Ghani, A., D.A. Wardle, A. Rahman and D.R. Lauren, 1996. Interactions between ${ }^{14} \mathrm{C}-$ labelled atrazine and the soil microbial biomass in relation to herbicide degradation. Biol. Fertil. Soils, 21: 17-22. Gigliotti, C., L. Allievi, C. Salardi, F. Ferrari and A. Farini, 1998. Microbial ecotoxicity and persistence in soil of the herbicide bensulfuron-methyl. J. Environ. Sci. Health, 33: 381398.Gold, R.E., H.N. Howell, B.M. Pawson, M.S. Wright and J.L. Lutz, 1996. Persistence and bioavailability of termicides to subterranean termites from five soil types and location in Texas. $\quad$ Sociobiology, 337-363. Grant, W.D. and A.W. West, 1987. Measurement of ergosterol diaminopimelic acid andglucosamine in soil evaluation as indicators of microbial biomass. J. Microb. Methods, 6:

47-53.

Gray, T.R.G., 1990. Methods for Studying the Microbial Ecology of Soil. In: Methods inMicrobiology, Grigorova, R. and J.R. Norris (Eds.). Academic Press, London, PP: 309342 .

Greaves, M.P., 1982. Effect of Pesticides on Soil Microorganisms. In: ExperimentalMicrobial Ecology, Burns, R.G. and J.H. Slater (Eds.). Blackwell, Oxford, pp: 613-630.

Greaves, M.P., H.A. Davies, J.A.P. Marsh and G.I. Wing-Field, 1976. Herbicides and soilmicroorganisms. $\quad$ Crit. $\quad$ Rev. Microbiol., $\quad 5:$ 1-38. Gregorich, E.A., M.A. Carter, D.A. Augers, C.M. Monreal and B.H. Ellert, 1994. Towards a minimum dataset to assess soil organic matter quality in agricultural soils. Can. J. Soil Sci., 74:

367-385.

Guan, J., C. Stehmann, S.W. Ellis, A. Kerkenaar and M.A. DeWaard, 1992. Ergosterolbiosynthesis in a cell free preparation of Penicillium italicum and its sensitivity to DMI fungicides. Pest. Biochem. Physiol., 42: 262-270.

Gupta, S. and V.T. Gajbhiye, 2002. Effect of concentration, moisture and soil type on the dissipation of flufenacet from soil. Chemosphere, 47: 901-906.

Hafez, H.F.H. and W.H.P. Thiemann, 2003. Persistence and biodegradation of diazinone and imidacloprid in soil. Proceedings of the XII Symposium Pest Chemica Congress, (PCC'03), Centre Universita Cattolica, Piacenza, pp: 35-42. 
Vol. 5, No. 05; 2020

ISSN: $2456-8643$

Haney, R.L., S.A. Senseman and F.M. Hons, 2002. Effect of roundup ultra on microbial activity and biomass from selected soils. J. Environ. Qual., 31: 730-735.

Hart, M.R. and P.C. Brookes, 1996. Soil microbial biomass and mineralisation of soil organic matter after 19 years of cumulative field applications of pesticides. Soil Biol. Biochem., 28:

1641-1649.

Hart, M.R. and P.C. Brookes, 1996. Effects of two ergosterol inhibiting fungicides on soil ergosterol and microbial biomass. Soil Biol. Biochem., 28: 885-892.

Hicks, R.J., G. Stotzky and P.V. Voris, 1990. Review and evaluation of the effects of xenobiotic chemicals on microorganisms in soil. Adv. Applied Microbiol., 35: 195-253.

Hussain, S.; Siddique, T.; Arshad, M. \& Saleem, M. (2009). BioremediationPhytoremediation of Pesticides: Recent Advances, Critical Review in Environmental

Science and Technology, Vol. 39, No. 10, pp. 843-907, ISSN 1064-3389.

Insam, H. and K.H. Domsch, 1988. Relationship between soil organic carbon and microbial biomass on chronosequences of reclamation sites. Microb. Ecol., 15: 177-188.

Jitender, K., Jai-Prakash, J. Kumar and J. Prakash 1993. Persistence of thiobencarb and butachlor in soil incubated at different temperatures. Proceedings of the Integrated Weed Management for Sustainable Agriculture International Society Weed Science, Nov. 18-20, India, pp:

$123-24$. Johnen, B.G. and E.A. Drew, 1978. Ecological effects of pesticides on soil microorganisms. Soil Sci., 123: 319-324. Johnsen, K., C.S. Jacobsen, V. Torsvik and J. Sorensen, 2001. Pesticide effects on bacterial diversity in agricultural soils-a review. Biol. Fertil. Soils, 33: 443-453. Jones, W.J. and N.D. Ananyeva, 2001. Correlations between pesticide transformation rate and microbial respiration activity in soil of different ecosystems. Biol. Fertil. Soils, 33: 477483.

Karpouzas, D.G., A. Walker, R.J.F. Williams and D.S. Drennan, 1999. Evidence for thenhanced biodegradation of ethoprophos and carbofuran in soils from Greece and the UK. Pest. $\quad$ Sci., 55: 301-311. Katayama, A. and K. Fujie, 2000. Characterization of Soil Microbiota with QuinoProfile. In: Soil Biochemistry. Bollag, J.M. and G. Stotzky (Eds.). Marcel Dekker, Inc., USA, pp: 303 347.

Kennedy, A.C., 1999. Bacterial diversity in agroecosystems, Agric. Ecosyst. Environ., 74: 65-76. Kent, A.D. And Triplett, E.W., 2002. Microbial communities and their interactions in soil and rhizosphere ecosystems, Annu. Rev. Microbiol., 56: 211-236.

Khan, S., Cao, Q., Hesham, A.B., Xia, Y.And He, J., 2007. Soil enzymatic activities and microbial community structure with different application rates of $\mathrm{Cd}$ and $\mathrm{Pb}$. J. environ. Sci., 19:834-840.

Khan, S., Hesham, A.L., Qiao, M., Rehman, S. And He, J., 2010. Effects of $\mathrm{Cd}$ and $\mathrm{Pb}$ on soil microbial community structure and activities. Environ. Sci. Pollut. Res., 17: 288-296. 
Vol. 5, No. 05; 2020

ISSN: $2456-8643$

Lodha, R.M. And Saxena, V., 1989.Pesticides and environmental pollution, Himanshu publication, pp. 4-9.

Lorenzo, D.E., Scott, G.I., Me. And Ross, P.E., 2001. Toxicity of pesticides to aquatic microorganisms: a review. Environ. Toxicol. Chem., 20: 84-98.

Moore, M.N., 2001. Biocomplexity: the post-genome challenge in ecotoxicology, Aquat. Toxicol., 59: 1-15.

Muñoz-Leoz, B., Garbisu, C., Charcosset, J., Sánchez-Pérez, J.M., Antigüedad, I. AndruizRomera, E., 2013.Non-target effects of three formulated pesticides on microbially-mediated processes in a clay-loam soil. Sci. Total Environ., 449:345-354.

WHO, 1990. Public health impact of pesticides used in agriculture. World Health Organization. Geneva, pp.88.

Zhao, C., Xie, H., Zhang, J., Xu, J. And Liang, S.,2013. Spatial distribution of organochlorine pesticides (OCPs) and effect of soil characters: A case study of a pesticide producing factory. Chemosphere, 90:

2381-2387.

Kodama, T. and S. Kuwatsuka, 1980. Factors for the persistence of parathion methyl parathion and fenitrothion in seawater. J. Pest. Sci., 5: 351-355. Kwok, I.M.Y. and R.T. Loeffer, 1993. The biochemical mode of action of some newer azole fungicides. Pest. $\quad$ Sci., $1-11$. Lundgren, B., 1981. Fluorescein diacetate as a stain of metabolically active bacteria in soil. Oikos, 36:

$17-22$.

Lynch, M.R, 1995. Procedures for Assessing The Environmental Fate And Ecotoxicity Of Pesticides. Society of Environmental Toxicology and Chemistry Brussels, Belgium. Matsumara, F. and G.M. Boush, 1971. Metabolism of Insecticides by Microorganisms. In: Soil Biochemistry, McLaren, A.D. and J. Skujins (Eds.). Vol.2,Marcel Dekker, Inc., New York, USA., pp:

320-336.

Moorman, T.B. and S.S. Harper, 1989. Transformation and mineralization of metribuzin in surface and subsurface horizons of a Mississippi Delta soil. J. Environ. Qual., 18: 302-306. Nair, D.R. and J.L.Schnoor, 1994. Effect of soil conditions on model parameters and atrazine mineralisation rates. Water Res., 28: 1199-1205. Nannipieri, P., S. Grego and B. Ceccanti, 1990. Ecological Significance of the Biological Activity in Soil. In: Soil Biochemistry, Bollag, J.M. and G. Stotzky (Eds.). Vol. 6, Marcel Dekker, New York, pp: 293-355. Newell, S.Y., 1992. Estimating Fungal Biomass and Productivity in Decomposing Litter. In: The Fungal Community its Organization and Role in the Ecosystem, Caroll, G.C. and D.T. Wicklow (Eds.). Marcel Dekker, Inc., New York, USA., pp: 521-561. Ohya, H., S. Fujiwara, Y. Komai and M. Yamaguchi, 1988. Microbial biomass and activity in urban soils contaminated with $\mathrm{Zn}$ and $\mathrm{Pb}$. Biol. Fertil. Soils, 6: 9-13. Pal, R., K. Chakrabarti, A. Chakraborty and A. Chowdhury, 2005. Pencycuron application to soils degradation and effect on microbiological parameters. Chemosphere, 60: 15131522.

Pal, R., K. Chakrabarti, A. Chakraborty and A. Chowdhury, 2005. Degradation of pencycuron in soil effect of application rate and soil conditions. Pest Manage. Sci., 61: 1220-1223.

Pankhurst, C.E., B.A. Hawke, H.J. McDonald, C.A. Kirby and J.C. Buckerfield et al., 
Vol. 5, No. 05; 2020

ISSN: $2456-8643$

1995. Evaluation of soil biological properties as potential bioindicators of soil health. Aust. J. $\quad$ Exp. Agric., $\quad 35:$ 1015-1028. Paul, E.A. and F.E. Clark, 1996. Composting Soil Microbiology and Biochemistry. 2nd Edn., Academic Press, USA., pp: 281-285. Paul, E.A. and R.A. Voroney, 1989. Field Interpretation of Microbial Biomass Activity and Measurements. In: Current Perspective in Microbial Ecology, Klug, M.J. and C.A. Reddy (Eds.). American Society of Microbiology, Washington, DC. Peacock, G.A. and M.W. Goosey, 1989. Separation of fungal sterols by normal phase high performance liquid chromatography: Application to the evaluation of ergosterol biosynthesis inhibitor. J. Chromatog., 469: 293-304. Perucci, P. and L. Scarponi, 1994. Effects of the herbicide imazethapyr on soil microbial biomass and various soil enzyme activities. Biol. Fertil. Soils, 17: 237-240. Perucci, P., C. Vischetti and F. Battistoni, 1999. Rimsulfuron in a silty clay loam soil effects upon microbiological and biochemical properties under varying microcosm conditions. Soil Biol. Biochem., 31: 195-204. Perucci, P., S. Dumontet, S.A. Bufo, A. Mazzatura and C. Casucci, 2000. Effects of organic amendment and herbicide treatment on soil microbial biomass. Biol. Fertil. Soils, 32: 17-23.

Ponnamperuma, F.N., 1972. The chemistry of submerged soils. Adv. Agron., 24: 29-96. | Prakash, N.B. and L.S. Devi, 2000. Persistence of butachlor in soils under different moisture regime. J. Ind. Soc. Soil Sci., 48: 249-256.

Raaijmakers, J.M.; Vlami, M. \& De Souza, J.T. (2002). Antibiotic Production by Bacterial Biocontrol Agents, Antonie van Leeuwenhoek, Vol. 81, Nos. 1-4, (December 2002),pp.537-547, ISSN 0003-6072. Racke, K.D., D.D. Fontaine, R.N. Yoder and J.R. Miller, 1994. Chlorpyriphos degradation in soil at termicidal application rates. Pest. Sci., 42: 43-51. Racke, K.D., M.W. Skidmore, D.J. Hamilton, J.B. Unsworth, J. Miyamoto and S.J. Cohen, 1997. Pesticide fate in tropical soils. Pure Applied Chem., 69: 1349-1371. Rath, A.K., B. Ramakrishnan, A.K. Rath, S. Kumaraswamy and N.Sethunathan et al., 1998. Effect of pesticides on microbial biomass of flooded soil.Chemosphere, 37: 661-671. Reddy, B.R. and N. Sethunathan, 1985. Salinity and the persistence of parathion in flooded $\begin{array}{lllll}\text { soil. } & \text { Soil } & \text { Biol. } & \text { Biochem., } & \text { 17: }\end{array}$ Reinke, H., A. Rosenzweig, J. Claus, M. Kreidi, C. Chisholm and P. Jensen, 1991. DPXE9636, experimental sulphonylurea herbicide for potatoes. Weeds, 4: 445-451. Roslycky, E.B., 1982. Glyphosate and the response of the soil microbiota. Soil Biol. Biochem., 14: 87-92. Sannino, F., M.T. Filazzola, A. Violante and L. Gianfreda, 1999. Fate of herbicides influenced by biotic and abiotic interactions. Chemosphere, 39: 333-341. Direct

Schneiders, G.E., M.K. Koeppe, M.V. Naidu, P. Horne, A.M. Brown and C.F. Much, 1993. Fate of rimsulfuron in the environment. J. Agric. Food Chem., 41: 2404-2410. CrossRef | 
Vol. 5, No. 05; 2020

ISSN: $2456-8643$

Schnurer, J. and T. Rosswall, 1982. Fluorescein diacetate hydrolysis as a measure of total microbial activity in soil and litter. Applied Environ. Microbiol., 43: 1256-1261.

Schuster, E. and D. Schroder, 1990. Side-effects of sequentially-applied pesticides on nontarget soil microorganisms: Field experiments. Soil Biol. Biochem., 22: 367-373. CrossRef | Direct Link |

Sparling, G.P., 1985. The Soil Biomass. In: Soil Organic Matter and Biological Activity, Vaughan, D. and R.E. Malcolm (Eds.). Martinus Nijoff Dr. W. Junk, Boston, Lanchester, pp:

223-239.

Stahl, P.D. and T.B. Parkin, 1996. Relationship of soil ergosterol concentration and fungal biomass. Soil Biol.

Biochem.,

28:

$847-855$.

CrossRef |

Sukul, P. and M. Spiteller, 2001. Influence of biotic and abiotic factors on dissipating $\begin{array}{llll}\text { metalaxyl in } & \text { soil. } & \text { Chemosphere, }\end{array}$

Thom, E., J.C.G. Ottow and G. Benckiser, 1997. Degradation of the fungicide difenoconazole in a silt loam soil as affected by pretreatment and organic amendment.Environ.Pollut.,96:409-414.

CrossRef |

Topp, E., T. Vallaeys and G. Soulas, 1997. Pesticides Microbial Degradation and Effects on Microorganisms. In: Modern Soil Microbiology, Van Elsas, J.D., J.T. Trevors and E.M.H. Wellington (Eds.). Mercel Dekker, Inc., New York, USA., pp:547-575.

Torstenssen, L. and J. Stenstrom, 1986. Basic respiration rate as a tool for prediction of pesticide persistence in soil. Toxic Asses.,1:57-72.

Trevors, J.T., 1998. Bacterial biodiversity in soil with an emphasis on chemicallycontaminated soils. Water Air Soil Pollut.,101:45-67.

Tu, C.M., 1992. Effect of some herbicides on activities of microorganisms and enzymes in $\begin{array}{lllll}\text { soil. J. Environ. } & \text { Sci. Health, }\end{array}$

Van Beelen, P. and P. Doelman, 1997. Significance and application of microbial toxicity tests in assessing ecotoxicological risks of contaminants in soil and sediment.Chemosphere,34:455-499.

Vischetti, C., C. Casucci and P. Perucci, 2002. Relationship between changes of soil microbial biomass content and benfluralin degradation. Biol. Fertil. Soils, 35: 13-17. 
Vol. 5, No. 05; 2020

ISSN: $2456-8643$

Vischetti, C., P. Perucci and L. Scarponi, 1995. The rimsulfuron herbicide in soil effect of its persistence on the growth and activity of microbial biomass at varying environmental conditions. Proceedings of The XII Interenational Symposium Environment Biogeochem Biosphere and Atmospheric Changes, (SEBBAC'95), Rio de Janeiro, Brazil, pp: 152-152.

Vischetti, C., P. Perucci and L. Scarponi, 2000. Relationship between rimsulfuron degradation and microbial biomass content in a clay loam soil. Biol. Fertil. Soils, 31:310314 .

Walker, A., Y.H. Moon and S.J. Welch, 1992. Influence of temperature soil moisture and soil characteristics on persistence of Alachlor. Pest. Sci., 35: 109-116.

Walker, N., 1975. Microbial Degration of Plant Protection Chemicals. In: Soil Microbiology, Walker, N. (Ed.). Butterwoths, London, pp; 181-196.

Walker, W.W., 1976. Chemical and microbiological degradation of malathion and parathion in an estuarine environment. J. Environ. Qual., 5: 210-216.

Walter-Echols, G. and E.P. Lichtenstein, 1978. Movement and metabolism of ${ }^{14} \mathrm{C}$-phorate in a flooded soil system. J. Agric. Food Chem., 26: 599-604.

Wardle, D.A. and D. Parkinson, 1990. Effects of three herbicides on soil microbial biomass $\begin{array}{llll}\text { and } \text { activity. } & \text { Plant } 28 .\end{array}$

Wardle, D.A. and D. Parkinson, 1990. Influence of the herbicide glyphosate on soil microbial community structure. Plant Soil, 122: 29-37.

Wardle, D.A. and D. Parkinson, 1992. Influence of the herbicides, 2,4-D and glyphosate on soil microbial biomass and activity a field experiment. Soil Biol. Biochem.,24:185-186.

Wardle, D.A. and D. Parkinson, 1991. Relative importance of the effect of 2,4-D, glyphosate, and environmental variables on the soil microbial biomass. Plant Soil, 134:209219.

Weber, K., 1976. Degradation of parathion in seawater. Water Res., 10: 237-241.

West, A.W., W.D. Grant and G.P. Sparling, 1987. Use of ergosterol diaminopimelic acid and glucosamine contents of soils to monitor changes in microbial populations. Soil Biol. Biochem., 19:

607-612.

Yoshida, T., 1978. Microbial Metabolism in Rice Soil. International Rice Research Institute, Philippines, pp: 445-463.

Yu, Y.L., Y.X. Chen, Y.M. Luo, X.D. Pan, Y.F. He and M.H. Wong, 2003. Rapid degradation of butachlor in a wheat rhizosphere soil. Chemosphere, 50: 771-774.

Zelles, L., I. Scheunert and F. Korte, 1985. Side effects of some pesticides on non-target 
International Journal of Agriculture, Environment and Bioresearch

Vol. 5, No. 05; 2020

ISSN: $2456-8643$

soil microorganisms. J. Environ. Sci. Health, 20: 457-488.

Zhu, G., H. Wu, J. Guo and F.M.E. Kimaro, 2004. Microbial degradation of fipronil in clay loam soil. Water Air Soil Pollut., 153: 35-44 